Article

\title{
Efficiency of Implementing Climate/Energy Targets of the Europe 2020 Strategy and the Structural Diversity between Old and New Member States
}

\author{
Malgorzata Klaudia Guzowska ${ }^{1, *(1)}$ and Barbara Kryk ${ }^{2}$ (D) \\ 1 Department of Econometrics and Statistics, Institute of Economics and Finance, University of Szczecin, \\ Mickiewicza 64, 71-101 Szczecin, Poland \\ 2 Department of Economics, Institute of Economics and Finance, University of Szczecin, Mickiewicza 64, \\ 71-101 Szczecin, Poland; barbara.kryk@usz.edu.pl \\ * Correspondence: malgorzata.guzowska@usz.edu.pl
}

Citation: Guzowska, M.K.; Kryk, B. Efficiency of Implementing Climate/Energy Targets of the Europe 2020 Strategy and the Structural Diversity between Old and New Member States. Energies 2021, 14, 8428. https://doi.org/10.3390/ en14248428

Academic Editor: Ricardo J. Bessa

Received: 12 November 2021

Accepted: 9 December 2021

Published: 14 December 2021

Publisher's Note: MDPI stays neutral with regard to jurisdictional claims in published maps and institutional affiliations.

Copyright: (c) 2021 by the authors. Licensee MDPI, Basel, Switzerland. This article is an open access article distributed under the terms and conditions of the Creative Commons Attribution (CC BY) license (https:/ / creativecommons.org/licenses/by/ $4.0 /)$.

\begin{abstract}
The most important goals included in the Europe 2020 Strategy are climate/energy targets, which determine not only the achievement of its other goals but also climate neutrality by 2050. This article aims to assess the efficiency of implementing the climate/energy targets of the Europe 2020 Strategy and to analyse changes over time, taking into consideration the structural diversity between the old (EU 15) and new EU members (EU 13) in the period of 2014-2018. The assessment of changes in the efficiency of climate/energy targets over time adds value to the evaluation methods used to date in this area. This was done using data envelopment analysis (DEA) and the Malmquist index. Earlier works usually specified only the level of target achievement, mostly jointly in relation to all of the goals of the Europe 2020 Strategy. The efficiency of their implementation at the macroeconomic level has not been studied. Furthermore, the added value of this paper consists in obtaining additional information concerning the internal structure and character of the studied efficiency of old and new member states. Changes in the efficiency level have been analysed with regard to the key climate/energy indicators used to monitor the Europe 2020 Strategy. Based on the results, the EU countries were divided into six groups with similar levels of efficiency in achieving energy and climate objectives and ranked using the DEA-Malmquist index according to changes in their level over time. This makes it possible not only to assess the performance of countries but also to formulate recommendations for decision-makers.
\end{abstract}

Keywords: efficiency; climate/energy targets; Europe 2020 Strategy; old and new member states

\section{Introduction}

Global climate change is one of the fundamental problems of our time. Its solution depends on close, original, and effective cooperation among all states. Meeting this condition has turned out to be most difficult, as evidenced by the unfulfilled climate and energy targets set in previous international agreements. The European Union (EU) has been engaged in implementing international climate/energy agreements for a long time now. As a community, it mostly reduced the global emission of greenhouse gasses, which made it a leader in fulfilling these obligations [1]. The EU consequently undertook steps obliging its members to carry out proper actions to this end. This has been expressed, for example, by the Europe 2020 Strategy valid between 2010 and 2020. The Europe 2020 Strategy constituted a recently ended 10-year programme of socio-economic development of the EU, including economic, social, and environmental targets. One of its three main priorities consisted of sustainable development: supporting the economy by taking advantage of resources in a more effective, more environmentally friendly, and more competitive manner [2]. The main goals, or rather a package of climate/energy targets corresponding to this priority (the so-called $3 \times 20$ ), were as follows: 
- Reducing $\mathrm{CO}_{2}$ emissions by at least $20 \%$ compared to 1990 or, if conditions allow it, even by $30 \%$;

- Increasing the share of renewable energy sources (RESs) in total energy consumption to $20 \%$;

- Increasing the efficiency of energy use by $20 \%$.

Their implementation is vital because they condition the achievement of other goals of the Europe 2020 Strategy, as well as the newly established goals in terms of climate neutrality by 2050. To measure them, a set of synthetic indicators have been established, which make it possible to compare the achievements at the national, community, and international levels [3].

The EU member states have undertaken various actions to achieve the climate/energy targets of the Europe 2020 Strategy. In the literature it is possible to find examples of assessing the level of attaining these goals [4], which allow for determining the degree of compliance of member states with their obligations in this area and provide a range of other information on this subject. However, there is a lack of publications evaluating the efficiency of their implementation at the macroeconomic level and of ones that would include a comparison with old and new EU members in the way this article does. Calculating the efficiency of countries' climate/energy targets not only compares their achievements but is also critical to achieving climate neutrality by 2050 . Efficiency constitutes a vital factor in determining decision-making at all levels of management. Understanding efficiency is of great practical importance for policymakers tasked with considering and ensuring sustainable socio-economic development, for example, by achieving climate/energy targets. Thus, it is worth verifying whether the implementation of such important goals for the Earth was effective in the EU member states.

Considering the existing research gap and the end of the validity period for the Europe 2020 Strategy, it was decided to address this issue. Thus, the aim of the article is to assess the efficiency of implementing climate/energy targets by the old and new EU member states in 2014-2018 and to compare the achieved results. The assumed turning point results from the lack of data concerning the national expenditure on environmental protection variables used for calculations. Also, the article attempts to answer three research questions:

- Was the implementation of the climate/energy targets effective in all countries of both member groups?

- How has the efficiency of implementing the climate/energy targets of the old and new EU member states changed over time?

- Are there significant differences in the efficiency level concerning implementing climate/energy targets between the old and new EU member states?

Non-parametric data envelopment analysis (DEA) and the DEA-Malmquist index have been used to achieve the aim of this study. The DEA method allows for a relative assessment of the efficiency and performance of a set of equivalent units, referred to as decision making units (DMUs). DEA is convenient for determining the efficiency of DMUs (in the article-old and new EU members) that are mutually comparable, i.e., take advantage of the same inputs and produce the same products but have different efficiencies. Determining whether a DMU is effective on the basis of observed data is equivalent to testing whether a DMU is at the boundary of the set of production possibilities [5].

Initially, the DEA method was mainly used to assess performance in economic sectors and national conditions [6,7], but over time, it began to be used in the public sphere, as reported by Štikarová [8]. For example, Stanickova [9] used it to assess the efficiency of achieving social goals, while Koçak et al. [10] and Ezici et al. [11] used it to assess environmental efficiency/eco-efficiency. The DEA method constitutes a convenient method of comparing national performance as an assumption for territory performance, because it assesses not only one factor, but also a set of different factors that determine the degree of economic development. Currently, DEA is the most common method for assessing the efficiency of similar objects over the same time horizon [12-14]. Apart from indicating the efficiency level, the DEA method also provides information on how much input or output 
variables must be changed for ineffective DMUs to become effective. Thanks to this feature, it contributes to the development of policy recommendations by delivering concrete results to decision makers.

The assessment of changes in the efficiency of climate/energy targets over time is an added value compared to the methods of assessment used to date in this area. No such study has been conducted. Usually, only the level of achieving targets has been determined, in most cases jointly in relation to all the goals of the Europe 2020 Strategy. This was done, among others, by Rappai [1], Pasimeni [3], and Gatto et al. [15]. The efficiency of achieving these goals at a macroeconomic level has not been studied. Therefore, the use of the DEA-Malmquist index for this should be considered a novel approach to research in this area. Moreover, obtaining additional information concerning the internal structure and nature of the studied efficiency of old and new EU members constitutes an added value. Changes in the efficiency level have been analysed with regard to the key climate/energy indicators used to monitor the implementation of the Europe 2020 Strategy and reported by Eurostat.

The remaining part of the article is organized as follows: a synthetic review of the literature concerning the measurement of efficiency using the DEA method, with particular emphasis on the DEA method at a macroeconomic level, the description of the research methodology, and the presentation of the research results.

The research shows that implementing climate/energy targets was ineffective in most countries, regardless of how long they were member states. Only seven countries were effective in their implementation. The article ends with a summary including analysis conclusions, answers to the posed questions, recommendations for policymakers, and suggestions for further research directions.

\section{Literature Review}

The EU stands out with great commitment to and experience in fighting climate change and ensuring sustainable energy. In 2015, the EU's progress in implementing climate/energy targets was significantly greater than that of other countries. Despite that, during the United Nations Climate Change Conference (COP 2015) conference in Paris, it turned out that the changes were insufficient in relation to the existing climate situation [16]. It was indicated that it is necessary to intensify actions in this area not only by the EU, but also by other countries [17]. It should be mentioned that the assessment made at that time, as well as the following ones [18], concerned only the degree of achieving the assumed targets. This is also what scientists dealing with this issue have done, e.g., Nordhaus [19], Capros et al. [20], Fotiou et al. [21], and Włodarczyk et al. [22]. The efficiency of implementing climate/energy targets has been assessed neither at the level of the member states nor at the EU level. According to the authors of this article, studying the efficiency of implementing climate/energy targets may determine the decisions of member states regarding further actions aimed at achieving climate neutrality by 2050 . If the efficiency of implementing new climate/energy goals is low or lacking, countries may delay actions aimed at achieving them, especially when it comes to responding to current socio-economic problems. For example, such cases took place during the global financial and economic crisis of 2008-2012. In such a situation, it seems extremely necessary to assess the efficiency of achieving climate/energy targets, in order to be able to search for ways to increase it, which would motivate countries to increase their efforts in this regard.

The DEA method, which was developed in 1978 by Americans A. Charnes and W. Cooper [23], is the most popular non-parametric method used to study the efficiency of similar units. It is a deterministic method that assumes the lack of a random component and does not require specifying a functional relation between inputs and outputs. The authors of the DEA method, based on the concept of productivity formulated by Debreu [24] and Farrell [25], defining the measure of productivity as the quotient of a single output and a single input, applied it to a multidimensional situation in which we may have more than one input and more than one output. 
Among the significant number of studies, the study closest to that undertaken in terms of this research is the one carried out by Staníčková [26]. She assessed the social dimension and the problems related to inequalities in the EU member states using the DEA method to present an assessment of socio-economic development and trends in EU countries in the context of the objectives of the Europe 2020 Strategy. In the study, she outlined the problems of the labour market, income differences, and poverty. She stated that decision-makers needed to be clear about social achievements, and therefore she paid particular attention to the main national targets of the Europe 2020 Strategy.

The remaining scientific studies, in which DEA was used to assess efficiency, did not refer to implementing any goals at the macroeconomic level in the context discussed in the article. They focused on estimating/assessing the efficiency of various types of expenses, actions, or solutions.

Yotova and Stefanova [27] analysed the efficiency of expenditure on higher education in EU member states from Central and Eastern Europe from a comparative perspective. The DEA method enabled them to indicate which of the studied countries achieved the best direct and indirect results thanks to the expenditure incurred on education.

Koçak et. al. [10] studied the environmental efficiency of disaggregated energy R\&D expenditures in OECD countries. They have determined which OECD countries ensure the environmental efficiency of energy R\&D spending and indicated the extent to which ineffective countries should change their development/R\&D spending to achieve efficiency.

Many researchers estimated the energy efficiency of using various alternative energy sources, which helped them determine which are most beneficial and which should be developed. This has been handled by, for example, Sobczyk and Sobczyk [28], Yuan and Huang [29], and Zhao et al. [30].

Wang et al. [31] took advantage of DEA to compare the performance of carbon reduction technology at the project level. In their research they showed which technologies for reducing carbon dioxide emissions are the most effective and presented suggestions for choosing the proper low-emission path for developing the energy sector.

Ezici et al. [11] researched the ecological efficiency of the manufacturing industry in the USA with an emphasis on the use of renewable and non-renewable energy. They have demonstrated that considering energy use impacts and economic outputs together within the scope of a global-trade-linked, cradle-to-gate life cycle provides a comprehensive understanding of the environmental and economic impacts of industrial activities.

Kyung-Taeki [32] and others assessed the efficiency of investments in renewable energy (wind, solar, and fuel cells) in Korea, considering policy objectives: public investment, technological development, and wider diffusion of these technologies in Korea. Based on the research results, they indicated to the Korean government that, from the point of view of government investments, wind energy is the most effective source of renewable energy.

Based on the presented synthetic literature review the following can be stated:

(1) Despite the great amount of research concerning various efficiencies using the DEA method, there are no publications on the efficiency of achieving the climate/energy targets of groups of countries in the context of the Europe 2020 Strategy.

(2) Many publications concern the broadly understood environmental issues, which predisposes DEA to take advantage of this in terms of the issue discussed in this article.

(3) In each publication, the results achieved thanks to using DEA allowed for the formulation of suggestions for decision-makers.

In this context, it can be considered that the DEA method is suitable for achieving the intended purpose of the article. The methodology of the research and its results are presented in detail in the following sections of the article.

\section{Materials and Methods}

Both parametric (econometric) and non-parametric approaches are most often used to determine the efficiency level of the facilities under study. 
The parametric approach is based on the production function, well known in the microeconomics theory, which determines the relationship between the company input and output. The parameters of this function are determined with classical tools of econometric estimation (e.g., stochastic frontier analysis) [33]. The non-parametric approach to efficiency analysis is based on linear programming methods, such as DEA and free disposal hull (FDH).

The DEA method is the most common method to measure the efficiency of a finite number of DMUs. DMUs are understood to be countries, businesses, public institutions, schools, libraries, hospitals, bank branches, and so on. The DEA method is based on the simple productivity concept (that defines the productivity measure as the quotient of a single output and a single input) but is applied to multidimensional situations with more than one input and more than one output. Linear programming was used to estimate technical efficiency measures and to create the first model using this method, called CCR (Charnes, Cooper, and Rhodes) or constant return-to-scale (CRS), where a constant scale effect was assumed. The DEA method should be applied to entities that pursue the same objective and operate under the same market conditions. Furthermore, the factors that characterize their activities are the same except for differences in the size and intensity of their use. In the case of this study, the DMUs are the 28 EU member countries.

In the DEA model, the efficiency of a given object is defined as follows [34]:

$$
U_{q}=\frac{\text { weighted } \sum \text { of outputs }}{\text { weighted } \sum \text { of inputs }}=\frac{\sum_{i=1}^{r} \mu_{i} y_{i q}}{\sum_{j=1}^{m} v_{i} x_{j q}}=\frac{\mu_{1} y_{1 q}+\mu_{2} y_{2 q}+\cdots+\mu_{r} y_{r q}}{v_{1} x_{1 q}+v_{2} x_{2 q}+\cdots+v_{m} x_{m q}}
$$

where

$r$-the number of outputs,

$m$-the number of inputs

$y_{r}$-the output values,

$x_{m}$ - the input values,

$\mu_{r}$ - the weights of the outputs, and

$v_{m}$ - the weights of the inputs.

As mentioned earlier, the DEA method allows us to determine the production frontier for a given DMU generated using linear programming methods. The DMUs located on the production frontier-considered efficient-are attributed with an efficiency coefficient equal to 1 (i.e., 100\%), while the units located below the curve-considered inefficient—will have an efficiency coefficient of less than 1 . The DMU can be regarded as technologically efficient if it lies on the efficiency frontier, and the units situated below the frontier can be regarded as technologically inefficient. The efficiency of a given DMU is measured in relation to other comparable units liable for analysis.

To classify DEA models, two criteria are used simultaneously: returns to scale and the model orientation. The first criterion indicates if either the inputs are minimized or the outputs are maximized. The second criterion defines what assumptions concerning returns to scale have been adopted in the model (variable, constant, or non-increasing).

\subsection{CRS DEA Model}

Similar to a basic model, the authors propose using an input-oriented CCR model. The CCR model assumes a decision unit in which the optimal combination of input and output variables is independent of the scope of the operation, which means that through this method, we measure the efficiency for each selected DMU.

$$
\text { Maximize } z=\sum_{k=1}^{r} u_{k} y_{k q}
$$

under the following conditions 


$$
\begin{gathered}
\sum_{k=1}^{r} u_{k} y_{k j}-\sum_{i=1}^{m} v_{i} x_{i j} \leq 0 j=1,2, \cdots n, \\
\sum_{i=1}^{m} v_{i} x_{i q}=1 u_{k} \geq \varepsilon \quad j=1,2, \cdots r, v_{k} \geq \varepsilon j=1,2, \cdots m .
\end{gathered}
$$

Note that, depending on what assumptions are made on the existence of the returns to scale, it is possible to estimate three types of efficiency measures: CRS, variable returns to scale (VRS), and non-increasing returns to scale (NIRS). The first measure resulting from the empirical production function assessed with the assumed CRS is designated by the best units in a given branch, due to which the efficiency measures achieved on the basis of this assumption do not consider the impact of a production output on efficiency. Subsequent measures achieved with the assumed VRS [35] or NIRS take into consideration the possible impact of the unit on production efficiency. Therefore, it is the comparison of these three measures that provides information about the relative economy of scale in a given branch [36] (Table 1).

Table 1. Economy of the scale of objects achieved on the basis of the relationship between the efficiency measures and the

\begin{tabular}{|c|c|c|}
\hline $\begin{array}{c}\text { Type of } \\
\text { DMU }\end{array}$ & $\begin{array}{l}\text { Relationship between } \\
\text { Efficiency Measures }\end{array}$ & Description \\
\hline I & $\begin{array}{c}\text { ecrs }=1, \text { evrs }=1 \\
\text { esvrs }=1, \text { esnirs }=1\end{array}$ & Efficient DMU, irrespective of accepted efficiency measures. \\
\hline II & $\begin{array}{c}\text { ecrs }<1, \text { evrs }=1 \\
\text { esvrs }<1, \text { esnirs }=1\end{array}$ & $\begin{array}{l}\text { DMU efficient under variable returns to scale }(e v r s=1) \text { and inefficient under constant } \\
\text { returns to scale }(\text { ecrs }<1) \text {, DMU inefficient in terms of the scale of employed factor } \\
(\text { esvrs }<1) \text { and operating in the region of increasing returns to scale }(\text { esnirs }=1) \text {. }\end{array}$ \\
\hline III & $\begin{array}{c}\text { ecrs }<1, \text { evrs }=1 \\
\text { esvrs }<1, \text { esnirs }<1\end{array}$ & $\begin{array}{l}\text { DMU efficient under variable returns to scale }(e v r s=1) \text { and inefficient under constant } \\
\text { returns to scale }(e c r s<1) \text {; DMU inefficient in terms of the scale of employed factor } \\
(\text { ecrs }<1) \text { and operating in the region of decreasing returns to scale }(\text { esnirs }<1) \text {. }\end{array}$ \\
\hline IV & $\begin{array}{c}\text { ecrs }<1, \text { evrs }<1 \\
\text { esvrs }<1, \text { esnirs }=1\end{array}$ & $\begin{array}{l}\text { DMU inefficient under both variable and constant returns to scale; DMU inefficient } \\
\text { due to a low level of employed factor }(\text { esvrs }<1) \text { and operating in the region of } \\
\text { increasing returns to scale }(\text { esnirs }=1) \text {. }\end{array}$ \\
\hline $\mathrm{V}$ & $\begin{array}{c}\text { ecrs }<1, \text { evrs }<1 \\
\text { esvrs }=1, \text { esnirs }=1\end{array}$ & $\begin{array}{l}\text { DMU inefficient under both variable and constant returns to scale; DMU } \\
\text { technologically inefficient and efficient in terms of production scale (esvrs =1, } \\
\text { esnirs = 1); DMU operating in the region of constant returns to scale. }\end{array}$ \\
\hline VI & $\begin{array}{c}\text { ecrs }<1, \text { evrs }<1 \\
\text { esvrs }<1, \text { esnirs }<1\end{array}$ & $\begin{array}{l}\text { DMU inefficient under both variable and constant returns to scale; DMU inefficient } \\
(\text { esvrs }<1, \text { esnirs }<1) \text { due to too high a level of the employed factor; DMU operating in } \\
\text { the region of decreasing returns to scale. }\end{array}$ \\
\hline
\end{tabular}
scale.

${ }^{1}$ Where ecrs is the efficiency measure under constant returns to scale (the so-called overall technical efficiency), evrs is the efficiency measure under variable returns to scale (the so-called pure technical efficiency), and enirs is the efficiency measure under non-increasing returns to scale, esvrs $=\frac{\text { ecrs }}{\text { evrs }}$ and esnirs $=\frac{\text { ecrs }}{\text { enirs }}$.

Another aspect of the study is to assess the efficiency of implementing the climate/ energy targets of the Europe 2020 Strategy in the EU countries by applying time-series dynamic efficiency analysis in the form of the input-oriented Malmquist productivity index (MPI).

The concept of MPI was proposed in 1953 [37]. The emergence of the DEA method in 1978 made the calculation of MPI a reality, which was gradually used in productivity analysis in different fields. In the empirical analysis, the DEA-Malmquist index was established by Fare et al. [38], and using the formula proposed by them, $M P I_{0}$ can be written in the following form:

$$
M P I_{0}=\left[\frac{\theta_{o}^{t}\left(x^{t+1}, y^{t+1}\right)}{\theta_{o}^{t}\left(x^{t}, y^{t}\right)} \cdot \frac{\theta_{o}^{t+1}\left(x^{t+1}, y^{t+1}\right)}{\theta_{o}^{t+1}\left(x^{t}, y^{t}\right)}\right]^{\frac{1}{2}}
$$


where $\theta_{o}^{s}\left(x^{t}, y^{t}\right)$ denotes the efficiency of the oth facility for the common technology of period $s$ and the technology of facility o of period $t$ and decomposes into two factors [5]:

Change of efficiency,

$$
\frac{\theta_{0}^{t+1}\left(x^{t+1}, y^{t+1}\right)}{\theta_{0}^{t+1}\left(x^{t}, y^{t}\right)}
$$

and technological progress,

$$
\left[\frac{\theta_{0}^{t}\left(x^{t+1}, y^{t+1}\right)}{\theta_{0}^{t}\left(x^{t}, y^{t}\right)} \cdot \frac{\theta_{0}^{t+1}\left(x^{t+1}, y^{t+1}\right)}{\theta_{0}^{t+1}\left(x^{t}, y^{t}\right)}\right]^{\frac{1}{2}}
$$

The MPI values characterize three groups of efficiency changes: improving (MPI $>1$ ), unchanging $(\mathrm{MPI}=1)$, and declining $(\mathrm{MPI}<1)$.

\subsection{Data Collection, Inputs, and Outputs}

This paper considers two different expenditure indicators of the old (EU 15) and new (EU 13) EU member countries from 2014 to 2018 as inputs. As outputs, it uses five indicators (Table 2). Two distinct groups of $28 \mathrm{EU}$ countries were considered, namely the EU 15 (Austria (AT), Belgium (BE), Denmark (DK), Finland (FI), France (FR), Greece (GR), Spain (ES), Netherlands (NL), Ireland (IE), Luxembourg (LU), Germany (DE), Portugal (PT), Sweden (SE), Great Britain (UK), and Italy (IT)) and the EU 13 (Cyprus (CY), Czech Republic (CZ), Estonia (EE), Hungary (HU), Latvia (LV), Lithuania (LT), Malta (MT), Poland (PL), Slovakia (SK), Slovenia (SI), Bulgaria (BG), Romania (RO), and Croatia (HR)). All data were obtained from Eurostat [39]. Descriptive statistics of input and output variables are depicted in Table A1 (see Appendix A. Descriptive Statistics).

Table 2. Indicators and data sources.

\begin{tabular}{lll}
\hline \multicolumn{1}{c}{ Name (Symbol) } & \multicolumn{1}{c}{ Unit of Measure } & Data Source \\
\hline \multicolumn{1}{c}{ Input indicators: } & Current prices, million euro & Eurostat \\
GDP & Million euro & Eurostat \\
National expenditure on environmental protection & & Eurostat \\
Output indicators: & Million tonnes of $\mathrm{CO}_{2}$ equivalent & Eurostat \\
Greenhouse gas emissions in ESD sectors & Million tonnes of oil equivalent & Eurostat \\
$\begin{array}{l}\text { Primary energy consumption } \\
\text { Final energy consumption }\end{array}$ & Million tonnes of oil equivalent & Eurostat \\
Energy productivity & Euro per kilogram of oil equivalent (KGOE) & Eurostat \\
Share of renewable energy in gross final energy consumption & Percentage & Eurostat \\
\hline
\end{tabular}

Before starting the calculations, it was necessary to prepare the data properly. Since in a DEA model all variables should be stimulants [40], a quotient transformation was applied to variables with de-stimulant characteristics (greenhouse gas emissions in ESD sectors, primary energy consumption, and final energy consumption).

For efficiency and MPI, MS Office Excel and EMS Software were used [41].

\section{Results}

To achieve the goal of the article, during the first stage of the research, four efficiency indicators for achieving climate/energy targets by EU member states were calculated based on three input-oriented DEA models (CRS, VRS, and NIRS) for all reference years, i.e., from 2014 to 2018, in the context of the Europe 2020 Strategy. Then, the researched countries were divided into six groups according to the level of their efficiency (Table 3). The analysis refers to the division into old and new member states.

During the analysed period, only seven of the same EU countries belonging to groups I and III were effective in achieving climate/energy targets. There were no countries in the second group. Until 2017, regardless of the adopted performance measures, only two 
countries from group I (LV and MT) were the most effective, and in 2018, they were joined by $\mathrm{CY}$, which was previously in group III. It was surprising that the greatest efficiency in this regard was achieved by countries that are new EU members, whose domestic expenditure on environmental protection was not high. This may result from the fact that wanting to reduce their developmental distance with regard to the old members, and to meet their environmental obligations, these countries intensified pro-ecological activities, at the same time using EU funds, which increased their adaptation capabilities. As a result, they significantly reduced the emission of greenhouse gases and increased energy efficiency. This contributed to a high degree of achieving climate and energy targets as well as the efficiency of their implementation. Similar conclusions are included in a report by the European Commission on the State of the Energy Union [17].

Table 3. Results of the efficiency of implementing climate/energy targets for EU countries in 2014-2018.

\begin{tabular}{|c|c|c|c|c|c|c|}
\hline $\begin{array}{l}\text { Type of } \\
\text { DMU }\end{array}$ & $\begin{array}{l}\text { Efficiency } \\
\text { Measures }\end{array}$ & 2014 & 2015 & 2016 & 2017 & 2018 \\
\hline I & $\begin{array}{c}\text { ecrs }=1, \text { evrs }=1 \\
\text { esvrs }=1, \text { esnirs }=1\end{array}$ & LV, MT & LV, MT & LV, MT & LV, MT & CY, LV, MT \\
\hline II & $\begin{array}{c}\text { ecrs }<1, \text { evrs }=1 \\
\text { esvrs }<1, \text { esnirs }=1\end{array}$ & $\mathrm{x}$ & $\mathrm{x}$ & $\mathrm{x}$ & $x$ & $\mathrm{x}$ \\
\hline III & $\begin{array}{c}\text { ecrs }<1, \text { evrs }=1 \\
\text { esvrs }<1 \text {, esnirs }<1\end{array}$ & $\begin{array}{l}\text { CY, DK, IE, LU, } \\
\text { SE }\end{array}$ & CY, IE, LU, SE & $\begin{array}{l}\text { CY, DK, IE, LU, } \\
\text { SE }\end{array}$ & CY, DK IE, LU, SE & $\begin{array}{l}\text { DK, IE, LU, } \\
\text { SE }\end{array}$ \\
\hline IV & $\begin{array}{c}\text { ecrs }<1, \text { evrs }<1 \\
\text { esvrs }<1, \text { esnirs }=1\end{array}$ & BG, CZ, EE, RO & BG, EE & BG, EE & BG, EE & $\begin{array}{l}\text { BE, BG, CZ, } \\
\text { EE, HU, SK, } \\
\text { SI }\end{array}$ \\
\hline $\mathrm{V}$ & $\begin{array}{c}\text { ecrs }<1, \text { evrs }<1 \\
\text { esvrs }=1, \text { esnirs }=1\end{array}$ & $\mathrm{x}$ & $\mathrm{x}$ & $x$ & NL & NL, PL \\
\hline VI & $\begin{array}{c}\text { ecrs }<1, \text { evrs }<1 \\
\text { esvrs }<1, \text { esnirs }<1\end{array}$ & $\begin{array}{l}\text { AT, BE, HR, FI, } \\
\text { FR, DE, GR, HU, } \\
\text { IT, LT, NL, PL, PT. } \\
\text { SK, SI, ES, UK }\end{array}$ & $\begin{array}{l}\text { AT, BE, HR, CZ, } \\
\text { DK, FI, FR, DE, } \\
\text { GR, HU, IT, LT, } \\
\text { NL, PL, PT, RO, } \\
\text { SK, SI, ES, UK }\end{array}$ & $\begin{array}{l}\text { AT, BE, HR, CZ, } \\
\text { FI, FR, DE, GR, } \\
\text { HU, IT, LT, NL, } \\
\text { PL, PT, RO, SK, } \\
\text { SI, ES, UK }\end{array}$ & $\begin{array}{l}\text { AT, BE, HR, CZ, } \\
\text { FI, FR, DE, GR, } \\
\text { HU, IT, LT, PL, } \\
\text { PT, RO, SK, SI, ES, } \\
\text { UK }\end{array}$ & $\begin{array}{l}\text { AT, HR, FI, } \\
\text { FR, DE, GR, } \\
\text { IT, LT, PT, } \\
\text { RO, ES, UK }\end{array}$ \\
\hline
\end{tabular}

During the reference period, the third group of countries meeting the efficiency condition only with variable returns from the scale, meaning technologically efficient, but on the verge of efficiency, included-depending on the year-five countries: DK, IE, LU, SE, and CY. However, for the year 2015, DK was placed in group VI. CY, as already mentioned, was in group III until 2017. After it changed groups, only the old EU member states remained in this group. DK and SE were in the group on the border of efficiency, and this was due to the fact that both countries had already been close to meeting the climate and energy targets (the so-called $3 \times 20$ ) of the Europe 2020 Strategy. Therefore, they undertook actions aimed at achieving them, guided more by the principle of solidarity than efficiency. IE, in turn, undertook the process of decarbonizing difficult sectors (e.g., fossil fuels, dairy farming, and road transport), which resulted in a significant reduction in $\mathrm{CO}_{2}$ per capita emissions. This was accompanied by a significant increase in energy efficiency and a reduction in final energy consumption, which contributed to an increase in the efficiency level concerning the implemented targets. Expenditure concerning implementing climate/energy targets was also significantly increased by LU at that time, which impacted the efficiency of that implementation.

The fourth group consists of countries that ineffectively implement climate/energy goals but operate in the area of increasing rates of returns on the scale. In their case, there is hope that increasing the scale of specific actions will have a positive impact on efficiency. In 2014, this group included only new EU members: BG, CZ, EE, and RO. In 2015-2017, only BG and EE remained in the group, and the other two fell to group VI. In 2018, BE, 
$\mathrm{CZ}, \mathrm{HU}, \mathrm{SI}$, and SK, which were promoted from group VI, appeared next to them. BE is the only old member state in this group. Its transition to a higher group took place thanks to a significant reduction in $\mathrm{CO}_{2}$ emissions, which confirmed the positive impact of increasing the volume of actions on efficiency. Unfortunately, actions taken in relation to the strategic goal-energy efficiency and RES-were insufficiently effective. This is in a way confirmed by, for example, research by Kryk and Guzowska [4] concerning the degree of implementing climate and energy goals in the EU.

The remaining countries in group IV are new EU member states. In their case, implementing climate and energy targets overlaps with the ongoing processes of transforming the structure of the economy, energy, and socio-economic problems. For these countries, the mere transition from group VI (with total inefficiency) to a higher one already means a positive change and hope for increasing the efficiency of the implemented targets in the near future. However, these countries are unlikely to be able to meet the climate/energy targets on their own. That is because, despite their considerable financial efforts, they still spend sums disproportionate to the needs. In their case, it is necessary to significantly increase expenditure for climate/energy purposes. The support planned in terms of the so-called energy transformation will constitute a great help $[42,43]$.

Group V is unique. It includes countries that are technologically ineffective in meeting climate/energy targets but are efficient in terms of production scale. It was only in 2017 that NL appeared in this group, and in 2018 PL also appeared. Both countries were promoted from group VI to $\mathrm{V}$ thanks to increased energy efficiency and reducing $\mathrm{CO}_{2}$ emissions, which had a positive impact on the efficiency of achieving the goals. The fact that PL belongs to this group is not surprising, because as a new member state it struggles with similar problems as the above-mentioned six countries from the so-called former Eastern Bloc in group IV. It is only surprising that NL is in this group, as it is an old EU member state. NL incurs quite significant expenditure on meeting climate/energy targets when compared to other EU countries, but it is running out of available options to achieve these targets. This has a negative impact on the efficiency of achieving the set goals. In the case of NL, increasing this efficiency will be favoured by, for example, more efficient, new technological solutions and pro-ecological innovations.

Group VI includes countries that are technologically ineffective from the point of view of meeting climate/energy targets and show scale inefficiency. In 2014, this group included a total of 17 countries, including 11 old members (AT, BE, FI, FR, DE, GR, IT, NL, PT, ES, and UK) and 6 new ones (HR, HU, LT, PL, SK, and SI). In 2018, its number decreased to 12 , because 6 countries moved to the higher groups (NL, PL, HU, SK, SI, and BE), and one (RO) fell from group IV. RO is the economically weakest member of the EU, and when it started to make up for the shortcomings in socio-economic development, its final energy consumption and energy intensity of the economies increased. With limited expenditure for implementing climate/energy targets, the efficiency of its implementation worsened, hence the decline to a lower group. The presence of highly developed, old member states, which incur significant expenditures on environmental and energy goals, in this group was surprising. In their case, the inefficiency of achieving climate/energy targets may be due to two reasons. First, despite the strategic target of reducing primary and final energy consumption, they grew over the entire studied period. The analysis of primary and final energy consumption shows that in 2018, the EU's primary energy consumption was $4.9 \%$ above the energy efficiency target in 2020 and $22.0 \%$ above the 2030 target, and final energy consumption was 3.2\% above the 2020 efficiency target and $17.0 \%$ above the 2030 target [44]. The largest final energy consumers in the EU are the old member states, especially DE, FR, UK, and IT. Admittedly, the growth rate of final energy consumption was slower than the GDP (this is an indicator of the relative independence of energy consumption from economic growth), which leads to a positive trend towards increasing the efficiency of European economies. Unfortunately, this did not provide a proper increase in the level of energy efficiency. Second, slowing down the pace of energy efficiency improvement is a serious concern. An analysis of the available data shows that improving the energy 
absorbency of the global economy is slowing down. An improvement of $1.2 \%$ in 2018 constitutes approximately half of the mean observed since 2010. This implies the need to make greater efforts to intensify the actions taken so far [45]. In the context of the above, it turned out that the old member states are ineffective from the point of view of achieving climate/energy targets. For that reason, among others, in December 2018, the European Parliament and the Council of the EU adopted the revised Energy Efficiency Directive (EED) [46]. The revised EED specifies that the EU's energy efficiency target should be at least $32.5 \%$ by 2030. In this document, energy efficiency has been recognized as a strong factor working in favour of achieving climate goals. Reducing energy consumption is a key element in the Commission's proposal for "A long-term strategic vision for Europe towards a prosperous, modern, competitive and climate neutral economy", presented in November 2018 [47]. This assumes the necessity for all EU countries to undertake greater efforts to intensify the actions taken so far.

The conducted analysis allows for a conclusion that most countries (21 out of 28) were ineffective in terms of achieving climate/energy targets, regardless of how long they were member states of the EU. However, it does not show how this efficiency has changed over time. During the second stage of the research, using the DEA-Malmquist index (MPI), changes concerning the efficiency of climate/energy targets in the studied period were estimated. The MPI was calculated for all EU countries, both in terms of year to year as well as for the overall change in efficiency between 2014 and 2018 (Table 4). The level of the synthetic MPI made it possible to organize the countries, from the most to the least effective, in terms of achieving climate/energy targets over time.

Table 4. Annual and overall MPI results for the reference period 2014-2018.

\begin{tabular}{|c|c|c|c|c|c|c|}
\hline \multirow[b]{2}{*}{ DMU } & \multicolumn{4}{|c|}{ Annual MPI Change } & \multicolumn{2}{|c|}{ Overall Period MPI Change } \\
\hline & 2014-2015 & 2015-2016 & 2016-2017 & $2017-2018$ & 2014- & \\
\hline Austria & 0.12 & 0.07 & 0.08 & 0.08 & Malta & 1.72 \\
\hline Belgium & 0.06 & 0.03 & 0.03 & 0.03 & Cyprus & 1.58 \\
\hline Bulgaria & 0.29 & 0.35 & 0.40 & 0.35 & Luxembourg & 1.55 \\
\hline Croatia & 0.58 & 0.52 & 0.51 & 0.53 & Latvia & 1.42 \\
\hline Cyprus & 1.47 & 0.93 & 0.93 & 0.99 & Estonia & 1.09 \\
\hline Czechia & 0.11 & 0.08 & 0.09 & 0.09 & Lithuania & 0.84 \\
\hline Denmark & 0.20 & 0.11 & 0.11 & 0.12 & Slovenia & 0.66 \\
\hline Estonia & 0.86 & 0.98 & 0.97 & 1.01 & Croatia & 0.60 \\
\hline Finland & 0.14 & 0.18 & 0.13 & 0.15 & Ireland & 0.41 \\
\hline France & 0.01 & 0.01 & 0.01 & 0.01 & Bulgaria & 0.35 \\
\hline Germany & 0.01 & 0.01 & 0.01 & 0.01 & Romania & 0.28 \\
\hline Greece & 0.16 & 0.16 & 0.14 & 0.15 & Slovakia & 0.24 \\
\hline Hungary & 0.17 & 0.14 & 0.16 & 0.15 & Portugal & 0.24 \\
\hline Ireland & 0.38 & 0.29 & 0.24 & 0.27 & Denmark & 0.20 \\
\hline Italy & 0.02 & 0.02 & 0.02 & 0.02 & Finland & 0.18 \\
\hline Latvia & 1.09 & 1.56 & 1.09 & 1.16 & Hungary & 0.18 \\
\hline Lithuania & 0.62 & 1.02 & 0.66 & 0.70 & Greece & 0.17 \\
\hline Luxembourg & 1.44 & 0.80 & 0.66 & 0.60 & Austria & 0.12 \\
\hline Malta & 1.60 & 1.00 & 1.14 & 1.08 & Sweden & 0.11 \\
\hline Netherlands & 0.04 & 0.02 & 0.02 & 0.02 & Czechia & 0.11 \\
\hline Poland & 0.04 & 0.04 & 0.04 & 0.04 & Belgium & 0.06 \\
\hline Portugal & 0.19 & 0.24 & 0.19 & 0.16 & Netherlands & 0.04 \\
\hline Romania & 0.20 & 0.23 & 0.30 & 0.28 & Poland & 0.04 \\
\hline Slovakia & 0.24 & 0.19 & 0.20 & 0.20 & Spain & 0.03 \\
\hline Slovenia & 0.63 & 0.51 & 0.49 & 0.51 & Italy & 0.02 \\
\hline Spain & 0.03 & 0.02 & 0.02 & 0.02 & United Kingdom & 0.02 \\
\hline Sweden & 0.09 & 0.11 & 0.08 & 0.09 & France & 0.01 \\
\hline United Kingdom & 0.02 & 0.01 & 0.01 & 0.01 & Germany & 0.01 \\
\hline
\end{tabular}


In the years 2014-2018, the level of the MPI varied in individual countries in a nonuniform manner. In general, in most countries-regardless of the membership status-the MPI decreased, indicating a deterioration in the efficiency of achieving climate/energy targets. The MPI increased only in the case of BG, EE, FI, LV, and LT. The annual change in the MPI of EU countries in 2014-2018 ranged from 0.01 to 1.47. However, values below 1 were dominant, meaning inefficiency. In the case of a complete change in the MPI, during the analysed period, this indicator ranged from a minimum of 0.01 to a maximum of 1.72 . However, values above 1-meaning efficiency-were determined in the case of only five countries: MT, CY, LU, LV, and EE. In the remaining countries, the MPI was lower than 1 , indicating the inefficiency of achieving the climate/energy targets. The differences in the value of MPI also indicate significant differences in the level of efficiency of achieving climate and energy targets between the EU member states. These differences, without exception, apply to both old and new member states.

\section{Discussion}

For years, the EU has been taking actions to achieve climate and energy targets. This is reflected in, among other things, the Europe 2020 Strategy [2], Strategy Energy 2020 [48], Clean Energy for All Europeans-“Winter Package” [49], and Long-Term Low-Carbon Development Strategy [47]. Currently, the documents setting out the current directions of action in this regard are the European Green Deal [50], the "Fit for 55" package [51], and the provisions of the Glasgow COP26 Climate Summit of 2021 [52]. The assumptions/guidelines/goals for sustainable development contained in these documents are more ambitious than before and coincide with the goals of Agenda 2030 [53]. These documents focus on transforming the energy sector (including moving away from coal use in power generation, increasing investment in zero-carbon sources, and increasing energy efficiency), reducing greenhouse gas (GHG) emissions across all sectors of the economy, and achieving climate neutrality by 2050. The completed Europe 2020 Strategy was a breakthrough in achieving climate/energy goals, so it serves as a reference point for the conducted research.

This paper aimed to assess the efficiency of the implementation of climate/energy targets of the Europe 2020 Strategy and to analyse its changes, taking into account the structural differences between the old (EU 15) and new EU members (EU 13) in the period of 2014-2018. The adopted set of indicators and the applied research method enabled, in addition to examining the efficiency, a broader assessment of the implementation of climate/energy targets of the Europe 2020 Strategy. The classification of EU countries into six groups (Table 3) was based on the relationship between the efficiency measures and the scale. However, only the first three groups (I, II, and III) include countries that effectively implement climate/energy targets, while the remaining groups (IV, V, and VI) include countries that are inefficient in this respect.

The study showed that out of all the EU countries, only one-fourth effectively met their climate/energy targets during the period studied. It is worth noting that these were the same countries in all the years studied. In 2018, among them, three countries-LV, MT, and CY-were the most effective, while four (from group III-DK, IE, LU, and SE) were effective only under VRS/efficient under VRS (evrs $=1)$. The obtained results are partially consistent with the results presented by Ligus and Peternek [54] and Tutak et al. [55]. According to them, the energy sustainability leaders in 2017 and 2018 were DK, LU, AT, and SE, respectively, with CY and BG at the bottom of the ranking. In both these studies, SE was the clear leader in energy and climate sustainability. SE's high position is due to having started its energy transition as early as the 1970s, moving away from fossil fuels towards RES. Also, SE has a long tradition of developing ambitious environmental policies: about a decade ago, Hultman et al. [56] studied factors influencing low-carbon energy transition and Lindmark et al. [57] reported energy transition and carbon dioxide reduction in the Swedish pulp and paper industry. This partial efficiency of SE needs to be explained. This is due to the high primary energy consumption per capita (only Luxembourg and 
Finland consume more) and the large fuel imports associated with economic growth [55]. This is accompanied by increased total GHG emissions, which reduces the efficiency of climate/energy targets.

The country with partial efficiency is DK, which also started the energy transition process in the 1970s, developing wind energy in particular. For the past three decades, DK has pursued its priority in developing renewable energy and has become energy selfsufficient [58]. Its energy system has evolved from dependence on imports and fossil fuels to self-sufficiency with a large share of renewable energy [59]. As a result, it already largely met the climate/energy targets of the Europe 2020 Strategy in 2018. However, RES alone did not meet domestic energy demand, which resulted in increased energy imports that began to outpace exports from 2014. As a consequence, the studied efficiency has decreased.

The partial efficiency of the implementation of climate/energy goals was also demonstrated by LU, which for years had little achievement in this area, although it was the richest EU country in terms of GDP per capita [60] and had the resources for energyenvironmental investments. The reasons for this were the highest energy consumption per capita in the EU (primary energy consumption, final energy consumption, and household final energy consumption per capita), low share of renewable energy in the energy mix, high dependence on energy imports, the highest $\mathrm{CO}_{2}$ emissions per capita in the EU, and high energy prices [55]. Between 2008 and 2015, energy demand and carbon emissions decreased significantly [61], which increased the efficiency of climate/energy targets. Unfortunately, since 2016, energy demand and $\mathrm{CO}_{2}$ emissions have started to increase again. However, the government has adopted ambitious targets for the energy sector, including a $50-55 \%$ reduction in $\mathrm{CO}_{2}$ emissions by 2030. At the moment, $\mathrm{LU}$ is facing a huge challenge in achieving these targets. It is hampered by low energy prices for consumers, which act as a disincentive to make the investments needed in energy efficiency and RES. In addition, LU is characterized by an energy mix using fossil fuels and a high demand for transport fuels, especially from transit freight trucks.

The LU divergence in climate/energy targets was also demonstrated in [62], where the potential relationship between RES share in electricity and real GDP per capita was analysed. The results indicated a positive but very low effect of GDP per capita on the RES share in electricity between 2007 and 2017 for EU countries, except for Luxembourg, where the relationship was reversed.

The results obtained in this article also partially agree with the findings of Balcerzak [63], who studied the level of implementation of all goals of the Europe 2020 Strategy by the old and new member states, but in the period of 2004-2013. His study shows that there is an increasing level of implementation of climate/energy goals in all member states, but the new EU countries demonstrate a lower rate of implementation of the above-mentioned goals than do the old EU countries.

A positive result in the conducted research is that new member countries LV, MT, and CY were most effective in meeting climate/energy targets. CY joined the first group only in 2018. Until 2018, only LV and MT belonged to the group of efficient countries. This result differs from the results of Tutak et al. [55], who reported low levels of energy/climate sustainability of new member countries, including CY and MT. In another publication [64], CY, as well as LU, was ranked low among EU countries from the point of view of energy performance. However, it should be noted that their analysis was for the years 2008-2016, so there are some differences in the results. On the other hand, our results partially converge with the findings of Rokicki and Perkowska [65]. The authors noted that countries in group I have clearly reduced GHG emissions (both total and from the energy sector), increased the share of RES in the energy mix, improved energy efficiency, and reduced the level of energy poverty.

A country heavily dependent on imported energy (almost 93\% in 2018) is CY. It does not have the conventional fuel resources on which its energy system is based and therefore has one of the highest GHG emissions from the energy sector and total GHG emissions per 
capita [66]. However, it is gradually increasing the use of RES to become independent of fossil fuel imports and to meet climate/energy targets. A number of programmes have been launched from EU funds, which have enabled a significant increase in energy efficiency and have a positive impact on the efficiency of the targets. MT and LV have done the same.

Analysis of the data in Table 3 shows that countries classified in groups IV, V, and VI were ineffective in meeting climate/energy targets. A negative surprise was that it included most of the old EU member states, which had much higher expenditures on climate/energy investments than the new countries during the entire period under study. The inclusion of new members in these groups was not too surprising, as these countries are catching up with years of backlog in this area and are forced to change the structure of the energy mix and rebuild the energy system. It was interesting that in 2014, group IV included only new EU members (BG, CZ, EE, and RO). In four years, the size of this group increased to seven (BE, BG, CZ, EE, HU, SK, and SI), and one old member country appeared in it. The promotion of new members to a higher group (CZ, HU, SK, and SI) was connected with the intensification of climate and energy activities.

The higher position of BG in relation to the placement of the old member states, which were placed in the lower groups in terms of (in)efficiency, is remarkable. In all the abovementioned publications, BG was listed in the last place in the rankings of EU countries regarding the level of development of energy-climate sustainability. However, it should be emphasized that most of the analyses presented there were performed in periods earlier than in this article. Meanwhile, BG, thanks to the policy of increasing the energy efficiency of buildings implemented in recent years, has significantly reduced energy consumption in this sector compared to the industrial sector, in contrast to the situation in the EU. BG has also reduced the energy intensity of the economy, including industry, as well as energy consumption. As a result, it was promoted to a higher group in terms of efficiency of operations. This was confirmed by Georgiev and Tsankov [45]. Their analysis shows that the continuous decrease in energy consumption since 1990 is the result of consistent legislative actions aimed at achieving the objectives of the Europe 2020 Strategy (reducing energy consumption and increasing energy efficiency) to improve the climate and reduce their carbon footprint in nature. The analysis of energy intensity showed that in the EU, the main energy-intensive sectors are households and services, while in Bulgaria, they are transport and industry. Therefore, BG should direct its efforts to improve energy efficiency.

When analysing the efficiency of climate/energy targets, one should also refer to the classification of most of the old member countries in the lowest groups in this respect. In 2018, in group VI, there were 12 countries (AT, HR, FI, FR, DE, GR, IT, LT, PT, RO, ES, and UK), including only 4 new ones. This can be explained by the fact that old countries, despite high spending on climate/energy goals, have high final energy consumption in transport and households (higher than in industry). With a high level of GDP per capita, this makes it difficult to increase energy efficiency and negatively affects the efficiency of climate/energy targets. These results are partly in line with the results of another publication [4], which assessed the implementation of the climate/energy targets of the Europe 2020 Strategy by the EU member states in 2010 and 2019. This research found that the new member states implemented the climate/energy targets of the Europe 2020 Strategy to a greater extent than did the old member states.

The authors of this paper have discussed only the most important and, in their opinion, interesting issues. However, this does not limit other possibilities of interpreting the results, or directions of research in this area, of the similarity analysis. The choice in this regard remains open.

\section{Conclusions}

The results presented in the article add value to the current state of knowledge and may contribute to other possibilities of monitoring progress in assessing the efficiency of the implementation of climate/energy goals in terms of modern energy and climate actions. 
These issues are not only an interesting research topic but also have an applied dimension because they allow practical recommendations for decision-makers to be specified.

The analysis confirmed that during the analysed period, only seven countries demonstrated efficiency in terms of achieving the climate and energy targets: LV, MT, CY, DK, IE, LU, and SE. However, the new EU members achieved the greatest efficiency among them. The remaining 21 countries were ineffective in this respect, regardless of how long they were members of the EU. In the case of countries that already almost achieved the set climate/energy targets in 2018, this suggests, among other things, that they implement them in accordance with the principle of solidarity, not efficiency.

The analysis of the level of MPI showed that the efficiency of implementing climate/energy targets varied in a non-uniform manner over time, regardless of the EU membership status. In general, the trend of annually decreasing MPI was dominant, with an increase in this indicator only for BG, EE, FI, LV, and LT. In the case of a complete change in MPI, only five countries-MT, CY, LU, LV, and EE-exhibited the studied efficiency. There are differences between them and the rest of the EU in terms of the efficiency of meeting climate/energy targets-sometimes quite significant.

Furthermore, the analysis carried out allows the following specific recommendations to be made:

1. All countries should increase the efficiency of their climate/energy targets, especially those 21 that have been doing so inefficiently. This is necessary to achieve the new targets in this area set in existing documents [50,51].

2. To increase the efficiency of climate/energy goals, it is necessary not only to activate the energy transition mechanism but also to ensure the greater efficiency of mechanisms for the exchange of good practices in this area.

3. There should be better monitoring and estimation of energy consumption in sectors where it is necessary to increase energy efficiency $[45,67]$.

4. The share of RES in energy generation is to be increased, especially in the situation of the declared departure from fossil fuels at COP26.

5. Due to the different situations of the EU countries, it is worth individualizing some of the so-called soft management instruments, but also to slightly tighten the monitoring and evaluation of the implementation of climate/energy goals [68].

Summing up, the conducted research has shown not only which EU member states have effectively achieved the climate/energy targets of the Europe 2020 Strategy, but also how much work yet awaits all EU member states to achieve energy neutrality by 2050 . The obtained results not only reflect the efficiency of implementing climate/energy targets by old and new EU member states, but also constitute a voice in the discussion on the methods and directions of actions to achieve climate neutrality by 2050 . Achieving this neutrality requires enormous effort from all countries. In such a situation, questions arise on how to increase this efficiency and how to motivate countries to continue to meet the newly set targets, which are, after all, more ambitious than the existing ones, under existing resource constraints and changing circumstances. On the road to a low-carbon society, different energy transition pathways are possible [69].

It should also be mentioned that this article presents only one option for assessing the efficiency of the implementation of climate/energy targets of the Europe 2020 Strategy. However, it would be interesting to examine the efficiency in question using other methods, especially since the available literature lacks publications on this topic.

Author Contributions: Conceptualization, B.K. and M.K.G.; methodology, M.K.G.; validation, M.K.G.; formal analysis, B.K. and M.K.G.; resources, B.K.; writing, B.K.; writing-review and editing, B.K. and M.K.G.; visualization, M.K.G.; project administration, B.K. All authors have read and agreed to the published version of the manuscript.

Funding: The project is financed within the framework of the program of the Minister of Science and Higher Education under the name "Regional Excellence Initiative" in the years 2019-2022, project number 001/RID/2018/19, with the amount of financing being PLN 10,684,000.00. 
Institutional Review Board Statement: Not applicable.

Informed Consent Statement: Not applicable.

Data Availability Statement: Not applicable.

Conflicts of Interest: The authors declare no conflict of interest.

\section{Appendix A. Descriptive Statistics}

Table A1. Descriptive statistics of input and output variables.

\begin{tabular}{|c|c|c|c|c|}
\hline & Mean & Std. Deviation & Min. & Max. \\
\hline \multicolumn{5}{|l|}{2014} \\
\hline \multicolumn{5}{|l|}{ Inputs (unit) } \\
\hline GDP & $503,303.80$ & $768,241.50$ & 8751.10 & $2,927,430.00$ \\
\hline $\begin{array}{c}\text { National expenditure on environmental protection } \\
\text { Output (unit) }\end{array}$ & \multicolumn{3}{|c|}{ Output (unit) } & $63,026.00$ \\
\hline Greenhouse gas emissions in ESD sectors & 88.51 & 116.77 & 1.29 & 436.79 \\
\hline Primary energy consumption & 56.31 & 77.28 & 0.87 & 308.29 \\
\hline Final energy consumption & 38.18 & 50.85 & 0.55 & 209.93 \\
\hline Energy productivity & 6.86 & 2.96 & 2.23 & 14.01 \\
\hline Share of renewable energy in gross final energy consumption & 19.37 & 11.58 & 4.47 & 51.82 \\
\hline \multicolumn{5}{|l|}{2015} \\
\hline \multicolumn{5}{|l|}{ Inputs (unit) } \\
\hline GDP & $530,578.80$ & $812,879.90$ & 9996.70 & $3,026,180.00$ \\
\hline $\begin{array}{c}\text { National expenditure on environmental protection } \\
\text { Output (unit) }\end{array}$ & \multicolumn{3}{|c|}{ Output (unit) } & $63,755.00$ \\
\hline Greenhouse gas emissions in ESD sectors & 89.97 & 117.86 & 1.30 & 444.08 \\
\hline Primary energy consumption & 54.86 & 74.64 & 0.75 & 295.93 \\
\hline Final energy consumption & 38.97 & 51.68 & 0.58 & 212.68 \\
\hline Energy productivity & 8.10 & 2.27 & 4.85 & 16.25 \\
\hline Share of renewable energy in gross final energy consumption & 19.95 & 11.67 & 4.99 & 52.95 \\
\hline \multicolumn{5}{|l|}{2016} \\
\hline \multicolumn{5}{|l|}{ Inputs (unit) } \\
\hline GDP & $535,155.30$ & $810,928.50$ & $10,567.40$ & $3,134,740.00$ \\
\hline \multicolumn{5}{|l|}{ Output (unit) } \\
\hline Greenhouse gas emissions in ESD sectors & 91.25 & 119.61 & 1.33 & 454.16 \\
\hline Primary energy consumption & 55.15 & 74.23 & 0.71 & 297.63 \\
\hline Final energy consumption & 39.70 & 52.44 & 0.58 & 216.81 \\
\hline Energy productivity & 8.17 & 2.31 & 4.60 & 15.68 \\
\hline Share of renewable energy in gross final energy consumption & 20.06 & 11.59 & 5.36 & 53.33 \\
\hline \multicolumn{5}{|l|}{2017} \\
\hline \multicolumn{5}{|l|}{ Inputs (unit) } \\
\hline GDP & $550,931.60$ & $825,356.30$ & $11,716.50$ & $3,259,860.00$ \\
\hline \multicolumn{4}{|l|}{ Output (unit) } & $69,046.00$ \\
\hline Greenhouse gas emissions in ESD sectors & 92.30 & 121.38 & 1.43 & 466.87 \\
\hline Primary energy consumption & 55.78 & 74.32 & 0.81 & 298.12 \\
\hline Final energy consumption & 40.12 & 52.61 & 0.62 & 218.57 \\
\hline Energy productivity & 8.35 & 2.57 & 4.64 & 17.45 \\
\hline Share of renewable energy in gross final energy consumption & 20.54 & 11.76 & 6.20 & 54.16 \\
\hline
\end{tabular}


Table A1. Cont.

\begin{tabular}{|c|c|c|c|c|}
\hline & Mean & Std. Deviation & Min. & Max. \\
\hline \multicolumn{5}{|l|}{2018} \\
\hline Inputs (unit) & & & & \\
\hline GDP & $569,310.90$ & $847,452.30$ & $12,594.80$ & $3,356,410.00$ \\
\hline $\begin{array}{c}\text { National expenditure on environmental protection } \\
\text { Output (unit) }\end{array}$ & $10,757.57$ & $16,437.50$ & 169.30 & $72,546.00$ \\
\hline Greenhouse gas emissions in ESD sectors & 91.10 & 117.48 & 1.38 & 434.05 \\
\hline Primary energy consumption & 55.46 & 73.54 & 0.82 & 292.15 \\
\hline Final energy consumption & 40.17 & 52.27 & 0.66 & 215.46 \\
\hline Energy productivity & 8.70 & 2.72 & 4.79 & 18.54 \\
\hline Share of renewable energy in gross final energy consumption & 21.11 & 11.56 & 7.34 & 54.65 \\
\hline
\end{tabular}

\section{References}

1. Rappai, G. Europe En Route to 2020: A new way of evaluating the overall fulfillment of the Europe 2020 strategic goals. Soc. Indic. Res. 2016, 129, 77-93. [CrossRef]

2. European Commission. Communication from the Commission: Europe 2020: A Strategy for Smart, Sustainable and Inclusive Growth; COM 2010; European Commission: Brussels, Belgium, 3 March 2010.

3. Pasimeni, P. The Europe 2020 Index. Soc. Indic. Res. 2013, 110, 613-635. [CrossRef]

4. Kryk, B.; Guzowska, M. Implementation of Climate/Energy Targets of the Europe 2020 Strategy by the EU Member States. Energies 2021, 14, 2711. [CrossRef]

5. Coelli, T.J.; Rao, D.S.P.; O’Donnell, C.J.; Battese, G.E. An Introduction to Efficiency and Productivity Analysis; Springer: New York, NY, USA, 2005.

6. Melecký, L. Use of DEA Approach to Measuring Efficiency Trend in Old EU Member States. In Proceedings of the 11th International Conference on Liberec Economic Forum, Liberec: Technical University Liberec, Sychrov, Czech Republic, 16-17 September 2013.

7. Lavado, R.; Cabanda, E. The Efficiency of health and Education Expenditures in the Philippines. Cent. Eur. J. Oper. Res. 2009, 17, 275-291. [CrossRef]

8. Štikarová, S. Economic growth, inequality and efficiency. In Working Paper No. 6; University of Economics Bratislava: Bratislava, Slovakia, 2014; pp. 1-9.

9. Stanickova, M. Can the implementation of the Europe 2020 Strategy goals be efficient? The challenge for achieving social equality in the European Union. Equilibrium 2017, 12, 383-398. [CrossRef]

10. Koçak, E.; Kınacı, H.; Shehzad, K. Environmental efficiency of disaggregated energy R\&D expenditures in OECD: a bootstrap DEA approach. Environ. Sci. Pollut. Res. 2021, 28, 19381-19390. [CrossRef]

11. Ezici, B.; Eğilmez, G.; Gedik, R. Assessing the eco-efficiency of U.S. manufacturing industries with a focus on renewable vs. non-renewable energy use: An integrated time series MRIO and DEA approach. J. Clean. Prod. 2019, 253, 119630. [CrossRef]

12. Chen, J.; Gao, M.; Li, D.; Song, M. Analysis of the rebound effects of fossil and nonfossil energy in China based on sustainable development. Sustain. Dev. 2020, 28, 235-246. [CrossRef]

13. Goto, M.; Sueyoshi, T. Sustainable development and corporate social responsibility in Japanese manufacturing companies. Sustain. Dev. 2020, 28, 844-856. [CrossRef]

14. Hermoso-Orzáez, M.J.; García-Alguacil, M.; Terrados-Cepeda, J.; Brito, P. Measurement of environmental efficiency in the countries of the European Union with the enhanced data envelopment analysis method (DEA) during the period $2005-2012$. Environ. Sci. Pollut. Res. 2020, 27, 15691-15715. [CrossRef] [PubMed]

15. Gatto, A.; Drago, C. A taxonomy of energy resilience. Energy Policy 2019, 136, 111007. [CrossRef]

16. Petri, F. Revisiting EU Climate and Energy Diplomacy: A Starting Point for Green Deal Diplomacy? Eur. Policy Brief 2020, 65, 1-9.

17. European Commission. 2020 Report on the State of the Energy Union Pursuant to Regulation (EU) 2018/1999 on Governance of the Energy Union and Climate Action; COM (2020) 950 Final; European Commission: Brussels, Belgium, 14 October 2020.

18. European Commission. EU SDG Indicator Set 2021 Result of the Review in Preparation of the 2021 Edition of the EU SDG Monitoring Report; Eurostat: Luxembourg, 2021.

19. Nordhaus, W. Integrated assessment models of climate change. NBER Rep. 2017, 3, 16-20.

20. Capros, P.; Kannavou, M.; Evangelopoulou, S.; Petropoulos, A.; Siskos, P.; Tasios, N.; Zazias, G.; DeVita, A. Outlook of the EU energy system up to 2050: The case of scenarios prepared for European Commission's "clean energy for all Europeans" package using the PRIMES model. Energy Strategy Rev. 2018, 22, 255-263. [CrossRef]

21. Fotiou, T.; de Vita, A.; Capros, P. Economic-engineering modelling of the buildings sector to study the transition towards deep decarbonisation in the EU. Energies 2019, 12, 2745. [CrossRef]

22. Włodarczyk, B.; Firoiu, D.; George, H.; Ionescu, G.H.; Ghiocel, F.; Szturo, M.; Markowski, L. Assessing the Sustainable Development and Renewable Energy Sources Relationship in EU Countries. Energies 2021, 14, 2323. [CrossRef] 
23. Charnes, A.; Cooper, W.W.; Rhodes, E. Measuring the efficiency of decision making units. Eur. J. Oper. Res. 1978, 2, 429-444. [CrossRef]

24. Debreu, G. The coefficient of resource utilization. Econom. J. Econom. Soc. 1951, 19, 273-292. [CrossRef]

25. Farrell, M.J. The measurement of productivity efficiency. J. R. Stat. Soc. 1957, 120, 253-290.

26. Stanickova, M. Efficient Implementation of the Europe 2020 Strategy Goals: Is Social Equality Achievable Reality or Myth Perhaps? Institute of Economic Research Working Papers; Institute of Economic Research (IER): Torun, Poland, 2017; Volume 120.

27. Yotova, L.; Stefanova, K. Efficiency of tertiary education expenditure in CEE countries: Data Envelopment Analysis. Econ. Altern. J. 2017, 25, 352-364.

28. Sobczyk, W.; Sobczyk, E.J. Varying the Energy Mix in the EU-28 and in Poland as a Step towards Sustainable Development. Energies 2021, 14, 1502. [CrossRef]

29. Yuan, B.; Huang, J.-N. Applying data envelopment analysis to evaluate the efficiency of R\&D projects-A case study of R\&D in energy technology. In Technology Commercialization; Springer: New York, NY, USA, 2002; pp. 111-134.

30. Zhao, H.; Guo, S.; Zhao, H. Provincial energy efficiency of China quantified by three-stage data envelopment analysis. Energy 2019, 166, 96-107. [CrossRef]

31. Wang, N.; Chen, J.; Yao, S.; Chang, Y.-C. A meta-frontier DEA approach to efficiency comparison of carbon reduction technologies on project level. Renew. Sustain. Energy Rev. 2018, 82, 2606-2612. [CrossRef]

32. Kyung-Taek, K.; Deok Joo, L.; Sung-Joon, P.; Yanshuai, Z.; Azamat, S. Measuring the efficiency of the investment for renewable energy in Korea using data envelopment analysis. Renew. Sustain. Energy Rev. 2015, 47, 694-702.

33. Kumbhakar, S.C.; Lovell, C.K. Stochastic Frontier Analysis; Cambridge University Press: Cambridge, UK, 2003.

34. Cooper, W.W.; Seiford, L.M.; Tone, K.; Zhu, J. Some models and measures for evaluating performances with DEA: Past accomplishments and future prospects. J. Prod. Anal. 2007, 28, 151-163. [CrossRef]

35. Banker, R.D.; Charnes, A.; Cooper, W.W. Some models for estimating technical and scale inefficiencies in data envelopment analysis. Manag. Sci. 1984, 30, 1078-1092. [CrossRef]

36. Wheelock, D.C.; Wilson, P.W. Explaining bank failures: Deposit insurance, regulation, and efficiency. Rev. Econ. Stat. 1995, 77, 689-700. [CrossRef]

37. Malmquist, S. Index numbers and indifference surfaces. Trab. Estadística 1953, 4, 209-242. [CrossRef]

38. Färe, R.; Grosskopf, S.; Lindgren, B.; Roos, P. Productivity changes in Swedish pharamacies 1980-1989: A non-parametric Malmquist approach. J. Prod. Anal. 1992, 3, 85-101. [CrossRef]

39. Eurostat. Available online: https:/ / ec.europa.eu/eurostat/data/database (accessed on 25 June 2021).

40. Golany, B.; Roll, Y. An application procedure for DEA. Omega 1989, 17, 237-250. [CrossRef]

41. Scheel, H. EMS: Efficiency Measurement System User's Manual 2000. Available online: http://www.holger-scheel.de/ems/ems. pdf (accessed on 9 September 2021).

42. European Commission. Regulation (eu) 2021/1056 of the European Parliament and of the Council of 24 June 2021 Establishing the Just Transition Fund. Off. J. Eur. Union 2021, L 231/1. Available online: http:/ / data.europa.eu/eli/reg/2021/1056/oj (accessed on 10 November 2021).

43. European Commission. Commission Implementing Regulation (EU) . . . . . of 15.9.2020 on the Union Renewable Energy Financing Mechanism, C/2020/6123 Final; European Commission: Brussels, Belgium, 2020.

44. Energy Consumption in 2018, News Release, 26/2020-4 February 2020. Available online: https:/ / ec.europa.eu/ eurostat (accessed on 10 November 2021).

45. Georgeva, N.; Tsankov, P. Analysis of energy consumption in the industrial sector in the European Union. In IOP Conference Series: Materials Science and Engineering; IOP Publishing: Bristol, UK, 2021.

46. Directive (EU) 2018/2002 of the European Parliament and of the Council Amending Directive 2012/27/EU on Energy Efficiency (Text with EEA Relevance.) PE/54/2018/REV/1. Off. J. Eur. Union 2018, L 328/210. Available online: http:/ / data.europa.eu/eli/ $\operatorname{dir} / 2018 / 2002$ / oj (accessed on 20 November 2021).

47. European Parliament. Resolution European Parliament Resolution of 14 March 2019 on Climate Change-A European Strategic Long-Term Vision for a Prosperous, Modern, Competitive and Climate Neutral Economy in Accordance with the Paris Agreement (2019/2582(RSP)); European Parliament: Strasbourg, France, 2019.

48. European Commission. Communication from the Commission to the European Parliament, the Council, the European Economic and Social Committee and the Committee of the Regions: Energy 2020: A Strategy for Competitive, Sustainable and Secure Energy; COM (2010) 639 Final; European Commission: Brussels, Belgium, 10 November 2010.

49. European Commission. Clean Energy for all Europeans; Publications Office of the European Union: Luxembourg, 2019.

50. European Parliament. Resolution European Parliament of 15 January 2020 on the European Green Deal (2019/2956 (RSP); European Parliament: Strasbourg, France, 2020.

51. European Council. Fit for 55: The EU's Plan for a Green Transition; Council of the European Union: Brussels, Belgium, 14 July 2020. Available online: https:/ / www.consilium.europa.eu/en/policies/eu-plan-for-a-green-transition/ (accessed on 18 November 2021).

52. Ware, J. End of coal in sight at COP 26. In Proceedings of the UN Climate Change Conference (COP26), Glasgow, UK, 11 April 2021. Available online: https:/ / ukcop26.org/end-of-coal-in-sight-at-cop26/ (accessed on 21 November 2021). 
53. United Nations. Transforming Our World: The 2030 Agenda for Sustainable Development. Resolution Adopted by the General Assembly on 27 July 2015. A/RES/69/313. 12; United Nations: New York, NY, USA.

54. Ligus, M.; Peternek, P. The Sustainable Energy Development Index-An Application for European Union Member States. Energies 2021, 14, 1117. [CrossRef]

55. Tutak, M.; Brodny, J.; Bindzár, P. Assessing the Level of Energy and Climate Sustainability in the European Union Countries in the Context of the European Green Deal Strategy and Agenda 2030. Energies 2021, 14, 1767. [CrossRef]

56. Hultman, N.E.; Malone, E.L.; Runci, P.; Carlock, G.; Anderson, K.L. Factors in low-carbon energy transformations: Comparing nuclear and bioenergy in Brazil, Sweden, and the United States. Energy Policy 2012, 40, 131-146. [CrossRef]

57. Lindmark, M.; Bergquist, A.-K.; Andersson, L.F. Energy transition, carbon dioxide reduction and output growth in the Swedish pulp and paper industry: 1973-2006. Energy Policy 2011, 39, 5449-5456. [CrossRef]

58. Parajuli, R. Looking into the Danish energy system: Lesson to be learned by other communities. Renew. Sustain. Energy Rev. 2012, 16, 2191-2199. [CrossRef]

59. Eikeland, P.; Inderberg, T.H.J. Energy system transformation and long-term interest constellations in Denmark: Can agency beat structure? Energy Res. Soc. Sci. 2016, 11, 164-173. [CrossRef]

60. Andrejiová, M.; Grincova, A.; Marasová, D. Study of the Percentage of Greenhouse Gas Emissions from Aviation in the EU-27 Countries by Applying Multiple-Criteria Statistical Methods. Int. J. Environ. Res. Public Health 2020, 17, 3759. [CrossRef] [PubMed]

61. Luxembourg 2020. Energy Policy Review. Country Report-March 2020. Available online: https://www.iea.org/reports/ luxembourg-2020 (accessed on 21 November 2021).

62. Simionescu, M.; Bilan, Y.; Krajňáková, E.; Streimikiene, D.; Gędek, S. Renewable Energy in the Electricity Sector and GDP per Capita in the European Union. Energies 2019, 12, 2520. [CrossRef]

63. Balcerzak, A.P. Europe 2020 Strategy and Structural Diversity between Old and New Member States. Application of Zero Unitarization Method for Dynamic Analysis in the Years 2004-2013. Econ. Sociol. 2015, 8, 190. [CrossRef]

64. Vavrek, R.; Chovancová, J. Energy Performance of the European Union Countries in Terms of Reaching the European Energy Union Objectives. Energies 2020, 13, 5317. [CrossRef]

65. Rokicki, T.; Perkowska, A. Diversity and Changes in the Energy Balance in EU Countries. Energies 2021, 14, 1098. [CrossRef]

66. IEA. Policies. Available online: https:/ / www.iea.org/countries/cyprus (accessed on 21 November 2021).

67. Liobikienè, G.; Butkus, M. The European Union possibilities to achieve targets of Europe 2020 and Paris agreement climate policy. Renew. Energy 2017, 106, 298-309. [CrossRef]

68. Knodt, M.; Schoenefeld, J.J. Harder soft governance in European climate and energy policy: Exploring a new trend in public policy. J. Environ. Policy Plan. 2020, 22, 761-773. [CrossRef]

69. Schmid, D.; Korkomaz, P.; Blesl, M.; Fahl, U.; Friedrich, R. Analyzing transformation pathways to a sustainable European energy system-Internalization of health damage costs caused by air pollution. Energy Strategy Rev. 2019, 26, 100417. [CrossRef] 